\title{
Smoking and subfertility: multivariable regression and Mendelian randomization analyses in the Norwegian Mother, Father and Child Cohort Study
}

Running title: Smoking and subfertility

Álvaro Hernáez ${ }^{1,2,3, \star}$, Robyn E. Wootton ${ }^{4,5}$, Christian M. Page ${ }^{1,6}$, Karoline H. Skåra ${ }^{1}$, Abigail Fraser $^{4,7,8}$, Tormod Rogne ${ }^{1,9,10}$, Per Magnus ${ }^{1}$, Pål R. Njølstad ${ }^{11,12}$, Ole A. Andreassen ${ }^{13,14}$, Stephen Burgess ${ }^{15,16}$, Deborah A. Lawlor ${ }^{4,7,8}$, Maria Christine Magnus ${ }^{1,4,7}$

1. Centre for Fertility and Health, Norwegian Institute of Public Health, Oslo, Norway.

2. Consorcio CIBER, M.P. Fisiopatología de la Obesidad y Nutrición (CIBEROBN), Instituto de Salud Carlos III, Madrid, Spain.

3. Blanquerna School of Health Sciences, Universitat Ramon Llull, Barcelona, Spain.

4. MRC Integrative Epidemiology Unit, University of Bristol, Bristol, UK.

5. Nic Waals Institute, Lovisenberg Diaconal Hospital, Oslo, Norway.

6. Department of Mathematics, University of Oslo, Oslo, Norway.

7. Population Health Sciences, Bristol Medical School, University of Bristol, Bristol, UK.

8. NIHR Bristol Biomedical Research Centre, Bristol, UK

9. Department of Chronic Disease Epidemiology, Yale University School of Public Health, New Haven, Connecticut, USA.

10. Gemini Center for Sepsis Research, Department of Circulation and Medical Imaging, NTNU Norwegian University of Science and Technology, Trondheim, Norway.

11. Department of Clinical Science, Center for Diabetes Research, University of Bergen, Bergen, Norway 
12. Children and Adolescent Clinic, Haukeland University Hospital, Bergen, Norway

13. Norwegian Centre for Mental Disorders Research, NORMENT, Division of Mental Health and Addiction, Oslo University Hospital, Oslo, Norway

14. Institute of Clinical Medicine, University of Oslo, Oslo, Norway

15. MRC Biostatistics Unit, University of Cambridge, Cambridge, UK.

16. Cardiovascular Epidemiology Unit, Department of Public Health and Primary Care, University of Cambridge, Cambridge, UK.

\section{Corresponding author:}

Alvaro Hernaez, PharmD, PhD

Centre for Fertility and Health, Norwegian Institute of Public Health

PO 222 Skøyen, 0213 Oslo, Norway

Telephone: (+47) 95523951

e-mail: alvaro.hernaez@fhi.no

ORCID: 0000-0001-8593-1477 
medRxiv preprint doi: https://doi.org/10.1101/2021.10.25.21265469; this version posted October 26, 2021. The copyright holder for this preprint (which was not certified by peer review) is the author/funder, who has granted medRxiv a license to display the preprint in perpetuity.

All rights reserved. No reuse allowed without permission.

ABSTRACT

3 Objective. To investigate the association between smoking-related traits and subfertility.

4 Design. Prospective study.

5 Setting. Nationwide cohort in Norway.

6 Patients. 28,606 women (average age 30) and 27,096 men (average age 33) with

7 questionnaire and genotype information from the Norwegian Mother, Father and Child

8 Cohort Study.

9 Intervention. Self-reported information on smoking (having ever smoked [both sexes], age

10 at smoking initiation [women only], smoking cessation [women only], and cigarettes

11 smoked per week in current smokers [both sexes]) was gathered. Genetically

12 predetermined levels or likelihood of presenting the mentioned traits were estimated for

13 Mendelian randomization (MR) analyses.

14 Main outcome measure. Subfertility, defined as time-to-pregnancy $\geq 12$ months.

15 Results. A total of $10 \%$ of couples were subfertile. In multivariable regression accounting

16 for age, years of education, body mass index, and number of previous pregnancies,

17 having ever smoked was not linked to subfertility in women or men. A higher intensity of

18 tobacco use in women who were current smokers was related to greater odds of

19 subfertility (+ 1 standard deviation [SD, 48 cigarettes/week]: odds ratio [OR] 1.12, 95\%

20 confidence interval [Cl] 1.03 to 1.21 ), also after adjusting for the partner's tobacco use.

21 Later smoking initiation (+ 1 SD [3.2 years]: OR 0.89, 95\% CI 0.84 to 0.95 ) and smoking

22 cessation (relative to not quitting: OR $0.83,95 \% \mathrm{Cl} 0.75$ to 0.93 ) were linked to decreased

23 subfertility in women who had ever smoked. Nevertheless, MR results were not

24 directionally consistent for smoking intensity and cessation and were imprecisely

25 estimated in two-sample MR, with wide confidence intervals that overlapped with the

26 multivariable regression results. In men, greater smoking intensity was marginally linked to 
medRxiv preprint doi: https://doi.org/10.1101/2021.10.25.21265469; this version posted October 26, 2021. The copyright holder for this preprint

(which was not certified by peer review) is the author/funder, who has granted medRxiv a license to display the preprint in perpetuity.

All rights reserved. No reuse allowed without permission.

27 greater odds of subfertility in multivariable analyses, but this association was attenuated

28 when adjusting for the partner's smoking intensity (+ 1 SD [54 cigarettes/week]: OR 1.05,

$2995 \% \mathrm{Cl} 0.96$ to 1.15$)$. MR estimates were directionally consistent but again imprecisely

30 estimated.

31 Conclusions. We did not find robust evidence of an effect of smoking on subfertility. This

32 may be due to a true lack of effect, weak genetic instruments, or other kinds of

33 confounding. The relevant limitations across all methods highlights the need for larger

34 studies with information on subfertility. 
medRxiv preprint doi: https://doi.org/10.1101/2021.10.25.21265469; this version posted October 26, 2021. The copyright holder for this preprint (which was not certified by peer review) is the author/funder, who has granted medRxiv a license to display the preprint in perpetuity.

All rights reserved. No reuse allowed without permission.

INTRODUCTION

36 Smoking is a well-known source of thousands of pro-oxidative and pro-inflammatory

37 compounds (1), capable of damaging reproductive tissues which in turn may compromise

38 fecundity (2-4). Observational studies in women have reported that active smoking was

39 linked to $14 \%$ greater odds of subfertility (trying to conceive for $\geq 12$ months) (5) and

40 smoking intensity was dose-dependently associated with greater subfertility risk (6).

41 Tobacco use has also been related to surrogate indicators of decreased fertility such as

42 accelerated follicular depletion and earlier menopause $(7,8)$. Although smoking has been

43 linked to oligozoospermia and morphological defects of sperm (9), two prospective studies

44 reported no association between tobacco use and subfertility in men $(10,11)$. Considering

45 this evidence, the Practice Committee of the American Society of Reproductive Medicine

46 has suggested a causal effect of tobacco use on clinical subfertility (12). However, existing

47 evidence is subject to numerous methodological limitations. The primary concerns raised

48 were that the relationship between smoking and decreased fertility has not been shown to

49 be sufficiently strong, residual confounding cannot be ruled out, and most studies were

50 retrospective and thus unable to reveal any potential exposure-to-effect sequence (12).

$51 \quad$ The use of complementary methodological approaches with different strengths and

52 sources of bias could help clarify whether there is a causal relationship between tobacco

53 use and subfertility (13). Mendelian randomization (MR) is based on the use of genetic

54 variants that are linked to an exposure (e.g. having ever smoked, a greater intensity of

55 current tobacco use) to assess the unconfounded effect of this exposure on a certain

56 outcome (e.g. subfertility) (14). It can be performed using data from a single sample (one-

57 sample MR: exposure, outcome, and genetic variants are measured in the same

58 population) or from two samples (two-sample MR: the association between genetic

59 variants and the exposure are assessed in one population and the association between

60 genetic variants and the outcome are studied in a second population) (15). In this paper, 
61 we compare results from multivariable logistic regression, one-sample MR, and two-

62 sample MR, considering that these are affected by different and unrelated sources of bias

63 when studying the association between smoking-related traits and subfertility (15-17)

64 (Table 1). Similar results in all of them would allow for more robust conclusions (13).

Our aim was to investigate the association between tobacco use and subfertility in

66 women and men by multivariable logistic regression and one- and two-sample MR.

67

68

69

METHODS

70

71 Study participants

72 Our study used data from the Mother, Father and Child Cohort Study (MoBa) $(18,19)$. The

73 MoBa Study is a population-based pregnancy cohort study conducted by the Norwegian

74 Institute of Public Health. Pregnant women and their partners across Norway were

75 recruited between 1999 and 2008 at the time of the routine ultrasound screening (around

$7618^{\text {th }}$ gestational week). The cohort now includes 114,500 children, 95,200 mothers and

7775,200 fathers. The current study is based on version \#12 of the quality-assured data.

78 For the current study, we defined a subsample of parents with available genotype

79 data and pre-pregnancy information on tobacco use. The genotype data in this study came

80 from blood samples gathered from both parents during pregnancy (20) and followed the

81 pipeline described by Helgeland et al (genotype calling, imputation, and quality control)

82 (21). Our work is described according to the STROBE guidelines for reporting MR and

83 cohort studies $(22,23)$.

84

85 Tobacco use 
medRxiv preprint doi: https://doi.org/10.1101/2021.10.25.21265469; this version posted October 26, 2021. The copyright holder for this preprint (which was not certified by peer review) is the author/funder, who has granted medRxiv a license to display the preprint in perpetuity.

All rights reserved. No reuse allowed without permission.

86 Parents responded to questions related to their smoking habits in the questionnaire

87 completed at recruitment. First, they reported if they had ever smoked. After an affirmative

88 answer, participants reported their age when they started smoking, if they were smokers

89 when they conceived, if they had quit smoking (and the date when they quit), and the

90 amount of cigarettes per week they currently smoked (or used to smoke for former

91 smokers). Using these data, we defined three exposure variables: ever smoker (yes/no,

92 available for the whole population), age at smoking initiation (continuous, available in

93 current/former smokers), and smoking cessation (yes/no, available in current/former

94 smokers). In addition, we computed the average cigarettes smoked per week at

95 conception or during the two years prior to conception (continuous, available in current

96 smokers and in participants who smoked at this time).

97

98 Selection of genetic variants and generation of instrumental variables

99 Genetic instruments were extracted from the most recent genome-wide association study

100 (GWAS) on smoking-related traits (24). It included more than 1.2 million individuals (none

101 of them participated in the MoBa cohort) and reported 378 conditionally independent single

102 nucleotide polymorphisms (SNPs) associated with smoking initiation, 10 linked to the age

103 of smoking initiation, 24 related to smoking cessation, and 55 associated with smoking

104 heaviness (cigarettes per week) (24). Independent SNPs were defined according to

105 linkage disequilibrium blocks across the genome using the methods by Li $\mathrm{J}$ et al., Gao X et

106 al., and Chen $Z$ et al. (25-27), presented a minor allele frequency $\geq 0.1 \%$ and were

107 associated with their respective phenotypes according to the standard genome-wide

108 significance threshold $\left(p<5 \times 10^{-8}\right)$. A total of 355, 10, 23, and 50 independent SNPs were

109 available for smoking initiation, age of smoking initiation, smoking cessation, and smoking

110 heaviness, respectively, in the MoBa genotype database. 
112 (GRS) by multiplying the number of risk alleles by the effect estimate of each variant and

113 dividing this value by the total number of SNPs (28). SNPs were used individually as the

114 genetic instruments in the two-sample MR.

Subfertility

117 Women were asked at recruitment if the pregnancy was planned and to provide

118 information on how many months it had taken them to conceive (19). The answer options

119 were "<1 month", "1-2 months" and "3 or more months". If the mother responded "3 or

120 more months", she was asked to further specify how many months they were trying to

121 conceive. We defined subfertility as trying to conceive for $\geq 12$ months or having used

122 assisted reproductive technologies. Those reporting trying for $<12$ months (defined as

123 fertile) were included in the reference group. Participants involved in unplanned

124 pregnancies were excluded.

Other variables

127 Information on the age of the participants (continuous), educational level (years of

128 education equivalent to the US system $(29,30)$, continuous), pre-pregnancy body mass

129 index (BMI, continuous), and previous number of deliveries $(0,1,2$, or $\geq 3)$ was gathered in 130 the baseline visit of the study as potential confounders.

Ethical approval

133 The MoBa cohort is conducted according to the Declaration of Helsinki for Medical

134 Research involving Human Subjects. The establishment of MoBa and initial data collection

135 was based on a license from the Norwegian Data Protection Agency. It is now based on

136 regulations related to the Norwegian Health Registry Act. Participants provided a written 
medRxiv preprint doi: https://doi.org/10.1101/2021.10.25.21265469; this version posted October 26, 2021. The copyright holder for this preprint (which was not certified by peer review) is the author/funder, who has granted medRxiv a license to display the preprint in perpetuity.

All rights reserved. No reuse allowed without permission.

137 informed consent before joining the cohort. This project was approved by the Regional

138 Committee for Medical and Health Research Ethics of South/East Norway (reference:

139 2017/1362).

141 Statistical analyses

142 Normally distributed continuous variables were described by means and standard

143 deviations (SD), non-normally distributed continuous variables by medians and $25^{\text {th }}-75^{\text {th }}$

144 percentiles, and categorical variables by proportions. Differences in baseline

145 characteristics between subfertile and fertile parents, and between participants with and

146 without genotype information in the MoBa cohort, were investigated by t-tests in normally

147 distributed continuous variables, Mann-Whitney U-tests in non-normally distributed

148 continuous variables, and chi-squared tests in categorical variables.

$150 \quad$ Multivariable regression analyses

151 We assessed the association between smoking-related traits and subfertility in women and

152 men by multivariable logistic regressions (adjusted for predefined subfertility risk factors:

153 age, years of education, BMI, and number of previous pregnancies $(31,32)$ ). For binary

154 exposures (smoking initiation and smoking cessation), we investigated the differences in

155 the odds of subfertility in those exposed compared with those who were not. For

156 continuous variables, we assessed the relationship between an increase in 1 SD in age at

157 smoking initiation (in ever smokers) and the number of cigarettes smoked per week (in

158 current smokers) with odds of subfertility. We also assessed whether a model using

159 smoothed cubic splines ( $K+4$ degrees of freedom) fitted the data better than a linear

160 function using a likelihood ratio test. In those traits in which there was information from

161 both parents (smoking initiation and number of cigarettes smoked per week), we further

162 adjusted logistic regression models for the partner's trait to minimize bias due to 
medRxiv preprint doi: https://doi.org/10.1101/2021.10.25.21265469; this version posted October 26, 2021. The copyright holder for this preprint (which was not certified by peer review) is the author/funder, who has granted medRxiv a license to display the preprint in perpetuity.

All rights reserved. No reuse allowed without permission.

163

164

165

166

167

168

169

170

171

172

173

174

175

176

177

178

179

180

analyses of smoking initiation, intensity, age at initiation, and cessation, respectively.

183 Finally, we used inverse variance weighted regression as the main two-sample MR 184 analysis (15).

185

186

187

188

assortative mating. Clustered standard errors were computed to account for non-

independence between pregnancies in participants with data on multiple pregnancies.

\section{One-sample Mendelian randomization}

We used logistic regression to estimate the genetically predicted likelihood of smoking initiation (in both sexes) and smoking cessation (in women), and linear regression to calculate the genetically predicted values of age at smoking initiation (in women) and the number of cigarettes smoked per week (in both sexes), using their respective GRSs as predictors. Next, we assessed the linear relationship between an increase in one SD in the genetically predicted traits and subfertility using logistic regression.

\section{Two-sample Mendelian randomization}

We first performed two GWASs (one for women and one for men) to obtain summary associations of each SNP, across the genome, with subfertility in the MoBa cohort. Full details of this procedure are available in the Supplemental Materials. Next, in these subfertility GWAS summary data, we looked for the SNPs related to each of the smoking traits and extracted the information related to their association with subfertility. We harmonized both datasets and excluded palindromic SNPs with minor allele frequencies close to $0.5(24,33)$. Following these exclusions, we had $301,43,7$ and 16 SNPs for

\section{Verification of MR assumptions}

The key assumptions of MR are: 1) the genetic instrument is robustly related to the exposure, 2) the genetic instrument is only associated with the outcome through the 
medRxiv preprint doi: https://doi.org/10.1101/2021.10.25.21265469; this version posted October 26, 2021. The copyright holder for this preprint (which was not certified by peer review) is the author/funder, who has granted medRxiv a license to display the preprint in perpetuity.

All rights reserved. No reuse allowed without permission.

189

exposure of interest, and 3) there is no confounding of the genetic instrument-outcome associations (15).

Regarding the first assumption, we checked the strength of the association between the genetic instruments and their phenotypes. For binary exposures we used logistic regression, area under the ROC curve, and pseudo- $R^{2}$ by the Nagelkerke method, and for continuous exposures we used linear regressions, $F$-statistics and $R^{2}$. Since weak instruments deviate MR causal estimates towards the null in two-sample MR, concordance between one-sample and two-sample MR reduces the concern that estimates might be influenced by weak instrument bias (34). We also performed the Robust Adjusted Profile Score two-sample MR method, which is unbiased by weak instruments $(34,35)$. The second assumption may be violated when the genetic instruments influence other risk factors for the outcome independently of the exposure of interest (horizontal pleiotropy) (16). To evaluate horizontal pleiotropy in one-sample MR, we checked the association of GRSs with known risk factors for subfertility. We studied the relationship between 1 SD increase in the GRS and the risk factors (age, years of education, BMI, number of previous deliveries) $(31,32)$ using linear regressions. If any of the GRSs was associated with a risk factor, we considered that a potential pleiotropic effect was present for all the smokingrelated traits. We then performed multivariable MR analyses if GWAS data for the potential pleiotropic variable was available (17). There was evidence of one or more of the smoking trait GRS associating with education and BMI and we were able to undertake multivariable MR for both. For education we used the GWAS by Lee JJ et al. ( $n=1,271$ independent SNPs, 1.1 million participants (36); 1,159 of the SNPs were available in MoBa). For BMI we used the GWAS by Yengo $L$ et al $(n=941$ independent SNPs, 700.000 participants (37); 896 of the SNPs were available in MoBa). We generated GRS for education and BMI using the same method as used for the smoking traits and then included the GRS for education and BMI in the one-sample MR regression models. (17). The genetic smoking 
medRxiv preprint doi: https://doi.org/10.1101/2021.10.25.21265469; this version posted October 26, 2021. The copyright holder for this preprint (which was not certified by peer review) is the author/funder, who has granted medRxiv a license to display the preprint in perpetuity.

All rights reserved. No reuse allowed without permission.

215 instruments also associated with age, and we performed stratified analyses according to

216 age (below vs. over the median). In addition, we estimated the association between the

217 GRSs for smoking traits and subfertility in non-exposed participants (the GRSs for age of

218 smoking initiation or smoking cessation in never smokers, and the GRS for current

219 smoking intensity in never + former smokers). As we would expect no association in non-

220 exposed participants, any evidence of one would indicate the presence of bias.

221 In two-sample MR we explored unbalanced horizontal pleiotropy through sensitivity

222 analyses comparing the main estimates to those obtained from MR-Egger, the weighted

223 median and weighted mode methods (38-40). The inverse variance weighted method

224 assumes no unbalanced horizontal pleiotropy as it forces the regression line through SNP-

225 exposure and SNP-outcome coordinates to go through zero. MR-Egger does not make

226 this assumption and it does not force the line through zero. A non-zero intercept is an

227 indication of unbalanced horizontal pleiotropy and the slope is subsequently corrected.

228 The weighted median and weighted mode analyses are valid if less than $50 \%$ of the weight

229 comes from SNPs that are not related to other risk factors for the outcome. Concordance

230 in the estimates across the different approaches reduces the concern regarding

231 unbalanced pleiotropy (38-40). We also checked for influential outliers in the variant-

232 specific causal estimates (indicative of horizontal pleiotropy) in scatterplots (38-40).

233 Finally, we evaluated between SNP heterogeneity, using Cochran's $Q$ and the Rücker's Q'

234 with the inverse variance weighted and Egger regression methods, respectively.

235 Heterogeneity indicates a possible violation of the MR assumptions, of which pleiotropy is

236 probably a major cause (38-40).

237 To reduce the potential for confounding of the genetic instrument-outcome

238 association due to population stratification (third assumption), we adjusted for the first 10

239 ancestry-informative principal components in the one-sample MR (41). 
medRxiv preprint doi: https://doi.org/10.1101/2021.10.25.21265469; this version posted October 26, 2021. The copyright holder for this preprint (which was not certified by peer review) is the author/funder, who has granted medRxiv a license to display the preprint in perpetuity.

All rights reserved. No reuse allowed without permission.

241 Software

242 Analyses were performed in R Software version 4.0.3 (packages: compareGroups,

243 estimatr, ggplot2, miceadds, and TwoSampleMR) and the GWASs to determine which

244 SNPs were associated with subfertility in the MoBa cohort in Plink v1.9 and GWAMA (42,

245 43). Code for data management and statistical analysis has been made available in

246 https://github.com/alvarohernaez/MR smoking subfertility MoBa/.

RESULTS

Description of the study population and genetic instruments

252 Our study population consisted of 28,606 women and 27,096 men with genotype

253 information (Figure 1). A total of $10 \%$ of the couples were subfertile. Women and men who

254 were subfertile were older, had a lower educational attainment, had a higher BMI, and

255 were more likely to be pregnant for the first time. In relation to smoking habits, there was a

256 higher proportion of ever smokers in subfertile couples and, among tobacco users,

257 smoking intensity was higher in subfertile individuals (Table 2). MoBa participants without

258 genotype data were not meaningfully different to those with genetic data in age, years of

259 education, BMI, or number of previous pregnancies compared to those with genotype

260 data. However, participants with genotype data were more likely to be subfertile, presented

261 a different proportion of ever smokers (women were less likely and men were more prone

262 to have ever smoked), and showed a lower smoking intensity among current smokers

263 (Supplemental Table 1).

264 Table 3 shows the associations of the GRS for each trait with smoking traits in

265 MoBa together with statistics related to instrument strengths. 
medRxiv preprint doi: https://doi.org/10.1101/2021.10.25.21265469; this version posted October 26, 2021. The copyright holder for this preprint (which was not certified by peer review) is the author/funder, who has granted medRxiv a license to display the preprint in perpetuity.

All rights reserved. No reuse allowed without permission.

267 Comparison of main multivariable regression, one-sample, and two-sample MR results

268 Figure 2A shows the confounder-adjusted associations, one-sample, and two-sample MR

269 results for each smoking trait in women. For smoking initiation, there were similar close to

270 the null results in both multivariable regression (odds ratio [OR] 1.03, 95\% confidence

271 interval [Cl] 0.95 to 1.11 ) and one-sample MR (OR 1.01, 95\% Cl 0.98 to 1.05 ), and an

272 inverse, but also close to the null, relationship in two-sample MR (OR $0.90,95 \% \mathrm{Cl} 0.75$ to

273 1.09). Regarding smoking intensity, it was linearly linked to greater odds of subfertility in

274 multivariable regression (1 SD increase in the number of cigarettes smoked per week [+48

275 cigarettes/week]: OR $1.12,95 \%$ Cl 1.03 to $1.21 ; p$-value non-linearity $=0.970)$, even after

276 adjusting for the partner's smoking heaviness (OR 1.10, 95\% Cl 1.01 to 1.19;

277 Supplemental Table 2). However, close to the null results were observed in one-sample

278 MR (OR $0.96,95 \% \mathrm{Cl} 0.89$ to 1.03$)$ and a notable inverse, but imprecisely estimated result

279 in two-sample MR analyses (OR $0.68,95 \% \mathrm{Cl} 0.40$ to 1.15). For age at smoking initiation,

280 a broadly similar pattern of results across the three measures was seen. We observed a

281 linear association between later smoking initiation and lower odds of subfertility in

282 multivariable analyses (1 SD increase in the age of smoking initiation in ever smokers

283 [+3.2 years]: OR $0.89,95 \% \mathrm{Cl} 0.84$ to $0.95 ; p$-value non-linearity $=0.933)$, close to the null

284 results in one-sample MR (OR $0.96,95 \% \mathrm{Cl} 0.91$ to 1.02$)$, and a greater, directionally

285 concordant but imprecise association in two-sample MR (OR 0.47, 95\% Cl 0.11 to 2.01 ).

286 Finally, for cessation amongst those who had ever smoked, there were similar, in terms of

287 OR, inverse associations in multivariable regression (OR $0.83,95 \% \mathrm{Cl} 0.75$ to 0.93 ) and

288 two-sample MR (OR 0.80, 95\% $\mathrm{Cl} 0.46$ to 1.38), the latter with wide confidence intervals,

289 whereas the result in one-sample MR was close to the null (OR $1.04,95 \% \mathrm{Cl} 0.99$ to

290 1.09).

291 Results from the three methods for smoking initiation in men showed broadly

292 similar patterns to those seen for women (Figure 2B). However, a linear association 
293 between higher smoking intensity and greater odds of subfertility was suggested in

294 multivariable analyses (1 SD increase in the number of cigarettes smoked per week [+54

295 cigarettes/week]: OR $1.08,95 \% \mathrm{Cl} 0.99$ to $1.18 ; p$-value non-linearity $=0.123$ ), attenuated when

296 adjusting for the partner's smoking intensity (OR 1.05, 95\% CI 0.96 to 1.15; Supplemental

297 Table 2). A similar but imprecise association was observed in two-sample MR (OR, 1.11,

$29895 \% \mathrm{Cl} 0.78$ to 1.59$)$, and close to the null results in one-sample $\mathrm{MR}$ (OR $1.02,95 \% \mathrm{Cl}$

2990.95 to 1.10$)$. It was not possible to complete multivariable regression and one-sample MR

300 analyses in men, because detailed information on smoking was not obtained from fathers

301 in MoBa. Nonetheless, in two-sample MR, close to the null, highly imprecise associations

302 were found for age of smoking initiation (OR $0.95,95 \% \mathrm{Cl} 0.19$ to 4.68 ) and smoking

303 cessation (OR $0.94,95 \% \mathrm{Cl} 0.57$ to 1.54$)$.

304

305 Sensitivity analyses

306 We observed associations between some smoking related GRSs and age (in women),

307 education years (in both sexes) and body mass index (in both sexes) (Supplemental

308 Table 3). Results of multivariable one-sample MR accounting for education and BMI and

309 age-stratified analyses were consistent with the main analyses (Supplemental Table 4).

310 No associations between the GRSs for smoking traits and subfertility were found in non-

311 smokers (Supplemental Table 5).

312 Regarding two-sample MR additional methods, between SNP heterogeneity,

313 potentially linked to horizontal pleiotropy, was observed for the genetic instrument for

314 smoking intensity in women, as well as highly imprecise MR estimates (Supplemental

315 Table 6, Supplemental Figure 1). 
medRxiv preprint doi: https://doi.org/10.1101/2021.10.25.21265469; this version posted October 26, 2021. The copyright holder for this preprint (which was not certified by peer review) is the author/funder, who has granted medRxiv a license to display the preprint in perpetuity.

All rights reserved. No reuse allowed without permission.

319 We found close to the null associations between smoking initiation and subfertility, using 320 confounder adjusted multivariable regression and MR in women and men. Regarding 321 smoking heaviness, it was associated with greater subfertility odds in both sexes in 322 multivariable regression. However, we found close to the null relationships in one-sample 323 MR, a suggested clinically important inverse association in two-sample MR in women, and 324 a substantial attenuation of the association in multivariable regression in men when 325 adjusted for the partner's smoking status. A similar pattern of association across the three 326 methods was observed for age at initiation in women, whereas there were consistent 327 inverse associations with smoking cessation between multivariable regression and two 328 sample MR in women. Taken together, our findings do not provide strong evidence for 329 effects of smoking on subfertility. However, results for two-sample MR were very 330 imprecise, highlighting the need for large collaborative GWAS of subfertility, one-sample 331 MR results may have been influenced by weak instrument and, despite numerous 332 sensitivity analyses, we cannot rule out completely bias due to horizontal pleiotropy in MR analyses or residual confounding in the multivariable regression analyses.

A link between smoking and subfertility has been reported in human studies since

335 the 1980s, particularly in women $(5,6,44)$. Nevertheless, the American Society of

336 Reproductive Medicine warned in 2018 of some methodological flaws in the available body

337 of evidence including the risk of residual confounding, the small magnitude of the 338 association, and the retrospective nature of most studies (14). We address these

339 limitations here by assessing the association between several smoking-related traits and 340 subfertility in a large prospective study comparing multivariable regression results to those 341 form one-sample and two-sample MR, undertaking several sensitivity analyses to explore 342 possible sources of bias. Our multivariable regression results were similar to previous 343 studies, including point estimates that were close to the null for several smoking traits (6, 344 44). The magnitude of these relationships was modest, and they were generally consistent 
medRxiv preprint doi: https://doi.org/10.1101/2021.10.25.21265469; this version posted October 26, 2021. The copyright holder for this preprint (which was not certified by peer review) is the author/funder, who has granted medRxiv a license to display the preprint in perpetuity.

All rights reserved. No reuse allowed without permission.

345 in direction to MR results, though with greater power and hence narrower confidence

346 intervals. In particular, confidence intervals for estimates for smoking intensity and age at

347 initiation (which are directly comparable) overlapped, suggesting the three sets of results

348 were consistent with each other. It is possible that residual confounding due to poorer

349 health status, worse diet quality, increased alcohol consumption, lower levels of physical

350 activity, etc. (45-47) could explain the decreased fertility among smokers in multivariable

351 analyses, with possible weak instruments in some of our one-sample MR analyses being

352 biased towards these confounded results. Moreover, we could not rule out bias due to

353 assortative mating completely (individuals who smoke are more likely to select a partner

354 who also smokes (48), which may distort any potential association in couple-based

355 outcomes such as fertility). Last, the genetic instruments for age of smoking initiation and

356 smoking cessation were also weak. Although we used several approaches to minimize the

357 likelihood of weak instrument bias, this could still have influenced findings, and in the two-

358 sample MR in particular results were imprecise, suggesting low power to reject the null

359 hypothesis $(33,38,39,49)$. Regarding men, we did not find any robust relationship

360 between tobacco-related habits and subfertility across methods. These results are in line

361 with previous prospective studies $(10,11)$.

Our work has some limitations. First, subfertility is a couple-dependent parameter

363 that was reported by mothers in the cohort, and we could not determine the cause (female

364 causes, male, or both). Second, MoBa is a pregnancy cohort, only including couples who

365 were able to conceive. Further studies considering couples who never conceived

366 (infertility) are needed. Subfertility is a less severe manifestation of infertility and, therefore,

367 an association between smoking-related traits and an absolute incapacity to conceive may

368 be possible. Third, our results may have been affected by selection bias as there was

369 some differences between participants with and without genetic data. In addition, smokers

370 are under-represented in the MoBa cohort relative to the whole Norwegian population (50). 
371 Nevertheless, associations between smoking and pregnancy outcomes (low birthweight,

372 placental abruption, and stillbirth) proved unaffected by selection bias in prior studies when

373 the MoBa cohort and the general Norwegian population were compared (50). Finally, our

374 study population (adult women and men of a northern European ancestry who were

375 capable of conceiving) restricts the generalizability. However, our work also presents

376 several strengths. To our knowledge, this is the first prospective study assessing the

377 relationship between smoking and subfertility using three complementary approaches

378 affected by different sources of bias that have been thoroughly investigated and

379 acknowledged. In addition, our study includes a relatively homogeneous population. This

380 aspect minimizes the risk of confounding due to population stratification in MR, together

381 with the adjustment for the first 10 principal components (41).

\section{CONCLUSIONS}

385 We did not find robust evidence of an effect of smoking on subfertility. This may be due to

386 a true lack of effect, weak genetic instruments, or other kinds of confounding. However,

387 the comparison of different analytical approaches with complementary sources of bias has

388 highlighted relevant limitations across all methods, and in particular highlights the needs

389 for larger studies with information on subfertility. 
medRxiv preprint doi: https://doi.org/10.1101/2021.10.25.21265469; this version posted October 26, 2021. The copyright holder for this preprint (which was not certified by peer review) is the author/funder, who has granted medRxiv a license to display the preprint in perpetuity.

All rights reserved. No reuse allowed without permission.

\section{DATA AVAILABILITY STATEMENT}

391 Consent given by the participants does not open for storage of data on an individual level

392 in repositories or journals. Researchers who want access to datasets for replication should

393 submit an application to datatilgang@fhi.no. Access to datasets requires approval from the

394 Regional Committee for Medical and Health Research Ethics in Norway and an agreement 395 with MoBa.

Source data of the GWAS on smoking initiation, age of smoking initiation, smoking cessation, and smoking intensity) are available in the Supplemental Tables of the article by

Liu M et al. (published in Nat Genet in 2019: https://www.nature.com/articles/s41588-018-

399 0307-5\#Sec14). Source data of the GWAS on education years are available in the

400 Supplemental Tables of the article by Lee JJ et al. (published in Nat Genet in 2018:

401 https://www.nature.com/articles/s41588-018-0147-3\#Sec34). Finally, source data of the

402 GWAS on BMI (Yengo L et al., Hum Mol Genet, 2018) are available in the GIANT

403 Consortium website

(https://portals.broadinstitute.org/collaboration/giant/index.php/GIANT consortium data fil

es\#GWAS Anthropometric 2015 BMI Summary Statistics).

\section{ACKNOWLEDGEMENTS}

409 The MoBa Cohort Study is supported by the Norwegian Ministry of Health and Care

410 Services and the Ministry of Education and Research. We thank all the participating

411 families in Norway who take part in this ongoing cohort study, and those who contributed

412 to the recruitment and the infrastructure of the cohort.

413 We thank the Norwegian Institute of Public Health for generating high-quality

414 genomic data. This research is part of the HARVEST collaboration, supported by the

415 Research Council of Norway (project reference: \#229624). We also thank the NORMENT 
medRxiv preprint doi: https://doi.org/10.1101/2021.10.25.21265469; this version posted October 26, 2021. The copyright holder for this preprint (which was not certified by peer review) is the author/funder, who has granted medRxiv a license to display the preprint in perpetuity.

All rights reserved. No reuse allowed without permission.

416 Centre for providing genotype data, funded by the Research Council of Norway (project

417 reference: \#223273), South East Norway Health Authority, and Stiftelsen Kristian Gerhard

418 Jebsen. We further thank the Center for Diabetes Research (University of Bergen) for

419 providing genotype information and performing quality control and imputation of the data in

420 research projects funded by the European Research Council Advanced Grant

421 SELECTionPREDISPOSED, Stiftelsen Kristian Gerhard Jebsen, the Trond Mohn

422 Foundation, the Research Council of Norway, the Novo Nordisk Foundation, the University

423 of Bergen, and the Western Norway Health Authority.

424 This work was performed on the TSD (Tjeneste for Sensitive Data) facilities, owned

425 by the University of Oslo, operated and developed by the TSD service group at the

426 University of Oslo, IT-Department (tsd-drift@usit.uio.no).

427 This paper does not necessarily reflect the position or policy of the Norwegian

428 Research Council.

\section{FUNDING}

432 The MoBa Cohort Study is supported by the Norwegian Ministry of Health and Care

433 Services and the Norwegian Ministry of Education and Research. This project received

434 funding from the European Research Council under the European Union's Horizon 2020

435 research and innovation program (grant agreement No 947684). This work was also partly

436 supported by the Research Council of Norway through its Centres of Excellence funding

437 scheme, project number 262700 , and the project “Women's fertility - an essential

438 component of health and well-being", number 320656. Open Access funding was provided

439 by the Folkehelseinstituttet/Norwegian Institute of Public Health. D.A.L. is a UK National

440 Institute for Health Research Senior Investigator (NF-SI-0611-10196) and is supported by

441 the US National Institutes of Health (R01 DK10324) and a European Research Council 
medRxiv preprint doi: https://doi.org/10.1101/2021.10.25.21265469; this version posted October 26, 2021. The copyright holder for this preprint (which was not certified by peer review) is the author/funder, who has granted medRxiv a license to display the preprint in perpetuity.

All rights reserved. No reuse allowed without permission.

442 Advanced Grant (grant agreement No 669545). The funders had no role in the collection,

443 analysis, and interpretation of data; in the writing of the report; or in the decision to submit

444 the article for publication.

445

446

447 CONFLICT OF INTEREST

448 D.A.L. receives (or has received in the last 10 years) research support from National and

449 International government and charitable bodies, Roche Diagnostics and Medtronic for

450 research unrelated to the current work. The rest of the authors declare that no competing

451 interests exist. 


\section{REFERENCES}

454 1. Talhout R, Schulz T, Florek E, van Benthem J, Wester P, Opperhuizen A.

455 Hazardous compounds in tobacco smoke. Int J Environ Res Public Health 2011;8:613-28.

456 2. Amiri M, Ramezani Tehrani F. Potential Adverse Effects of Female and Male

457 Obesity on Fertility: A Narrative Review. Int J Endocrinol Metab 2020;18:e101776.

$458 \quad 3 . \quad$ Broughton DE, Moley KH. Obesity and female infertility: potential mediators of 459 obesity's impact. Fertil Steril 2017;107:840-7.

$4604 . \quad$ Liu Y, Ding Z. Obesity, a serious etiologic factor for male subfertility in modern 461 society. Reproduction 2017;154:R123-r31.

462 5. Hyland A, Piazza K, Hovey KM, Tindle HA, Manson JE, Messina C et al.

463 Associations between lifetime tobacco exposure with infertility and age at natural

464 menopause: the Women's Health Initiative Observational Study. Tob Control 2016;25:706-

46514.

466 6. Baird DD, Wilcox AJ. Cigarette smoking associated with delayed conception. Jama $467 \quad 1985 ; 253: 2979-83$.

468 7. Adena MA, Gallagher HG. Cigarette smoking and the age at menopause. Ann Hum 469 Biol 1982;9:121-30.

470 8. Baron JA, La Vecchia C, Levi F. The antiestrogenic effect of cigarette smoking in 471 women. Am J Obstet Gynecol 1990;162:502-14.

472 9. Bundhun PK, Janoo G, Bhurtu A, Teeluck AR, Soogund MZS, Pursun M et al.

473 Tobacco smoking and semen quality in infertile males: a systematic review and meta-

474 analysis. BMC Public Health 2019;19:36.

475 10. de Mouzon J, Spira A, Schwartz D. A prospective study of the relation between 476 smoking and fertility. Int J Epidemiol 1988;17:378-84. 
477 11. Jensen TK, Henriksen TB, Hjollund NH, Scheike T, Kolstad H, Giwercman A et al.

478 Adult and prenatal exposures to tobacco smoke as risk indicators of fertility among 430

479 Danish couples. Am J Epidemiol 1998;148:992-7.

480 12. Penzias A, Bendikson K, Butts S, Coutifaris C, Falcone T, Gitlin S et al. Smoking

481 and infertility: a committee opinion. Fertil Steril 2018;110:611-8.

482 13. Lawlor DA, Tilling K, Davey Smith G. Triangulation in aetiological epidemiology. Int 483 J Epidemiol 2016;45:1866-86.

484 14. Lawlor DA, Harbord RM, Sterne JA, Timpson N, Davey Smith G. Mendelian

485 randomization: using genes as instruments for making causal inferences in epidemiology.

486 Stat Med 2008;27:1133-63.

487 15. Burgess S, Davey Smith G, Davies NM, Dudbridge F, Gill D, Glymour MM et al.

488 Guidelines for performing Mendelian randomization investigations. Wellcome Open Res

$489 \quad 2019 ; 4: 186$.

490 16. Davey Smith G, Hemani G. Mendelian randomization: genetic anchors for causal 491 inference in epidemiological studies. Hum Mol Genet 2014;23:R89-98.

492 17. Burgess S, Thompson SG. Multivariable Mendelian randomization: the use of 493 pleiotropic genetic variants to estimate causal effects. Am J Epidemiol 2015;181:251-60.

494 18. Magnus P, Birke C, Vejrup K, Haugan A, Alsaker E, Daltveit AK et al. Cohort

495 Profile Update: The Norwegian Mother and Child Cohort Study (MoBa). Int J Epidemiol

$496 \quad 2016 ; 45: 382-8$.

497 19. Magnus P, Irgens LM, Haug K, Nystad W, Skjaerven R, Stoltenberg C. Cohort

498 profile: the Norwegian Mother and Child Cohort Study (MoBa). Int J Epidemiol

$499 \quad 2006 ; 35: 1146-50$.

500 20. Paltiel L, Haugan A, Skjerden T, K; H, Bækken S, Stensrud NK et al. The biobank 501 of the Norwegian Mother and Child Cohort Study - present status. Norsk Epidemiologi $502 \quad 2014 ; 24: 29-35$ 
503 21. Helgeland $\varnothing$, Vaudel M, Juliusson PB, Lingaas Holmen O, Juodakis J, Bacelis J et

504 al. Genome-wide association study reveals dynamic role of genetic variation in infant and 505 early childhood growth. Nat Commun 2019;10:4448.

506 22. Davey Smith G, Davies NM, Dimou N, Egger M, Gallo V, Golub R et al. STROBE-

507 MR: Guidelines for strengthening the reporting of Mendelian randomization studies. PeerJ

508 Preprints 2019;7:e27857v1.

509 23. von Elm E, Altman DG, Egger M, Pocock SJ, Gøtzsche PC, Vandenbroucke JP.

510 Strengthening the Reporting of Observational Studies in Epidemiology (STROBE)

511 statement: guidelines for reporting observational studies. Bmj 2007;335:806-8.

512 24. Liu M, Jiang Y, Wedow R, Li Y, Brazel DM, Chen F et al. Association studies of up

513 to 1.2 million individuals yield new insights into the genetic etiology of tobacco and alcohol

514 use. Nat Genet 2019;51:237-44.

515 25. Chen Z, Liu Q. A new approach to account for the correlations among single

516 nucleotide polymorphisms in genome: wide association studies. Hum Hered 2011;72:1-9.

517 26. Gao X, Becker LC, Becker DM, Starmer JD, Province MA. Avoiding the high

518 Bonferroni penalty in genome-wide association studies. Genet Epidemiol 2010;34:100-5.

519 27. Li J, Ji L. Adjusting multiple testing in multilocus analyses using the eigenvalues of

520 a correlation matrix. Heredity (Edinb) 2005;95:221-7.

521 28. Choi SW, Mak TS, O'Reilly PF. Tutorial: a guide to performing polygenic risk score 522 analyses. Nat Protoc 2020;15:2759-72.

523 29. Barrabés N, Østli GK. Norsk standard for utdanningsgruppering 2016. In, 2016.

524 30. Rietveld CA, Medland SE, Derringer J, Yang J, Esko T, Martin NW et al. GWAS of 525126,559 individuals identifies genetic variants associated with educational attainment.

526 Science 2013;340:1467-71. 
527 31. Dribe M, Hacker JD, Scalone F. The impact of socio-economic status on net fertility

528 during the historical fertility decline: a comparative analysis of Canada, Iceland, Sweden,

529 Norway, and the USA. Popul Stud (Camb) 2014;68:135-49.

530 32. Sharma R, Biedenharn KR, Fedor JM, Agarwal A. Lifestyle factors and

531 reproductive health: taking control of your fertility. Reprod Biol Endocrinol 2013;11:66.

532 33. Burgess S, Bowden J, Fall T, Ingelsson E, Thompson SG. Sensitivity analyses for

533 robust causal inference from Mendelian randomization analyses with multiple genetic

534 variants. Epidemiology (Cambridge, Mass) 2017;28:30.

535 34. Barry C, Liu J, Richmond R, Rutter MK, Lawlor DA, Dudbridge F et al. Exploiting

536 collider bias to apply two-sample summary data Mendelian randomization methods to one-

537 sample individual level data. medRxiv 2020.

538 35. Zhao Q, Wang J, Hemani G, Bowden J, Small DS. Statistical inference in two-

539 sample summary-data Mendelian randomization using robust adjusted profile score. The

540 Annals of Statistics 2020;48:1742-69, 28.

541 36. Lee JJ, Wedow R, Okbay A, Kong E, Maghzian O, Zacher M et al. Gene discovery

542 and polygenic prediction from a genome-wide association study of educational attainment

543 in 1.1 million individuals. Nat Genet 2018;50:1112-21.

544 37. Yengo L, Sidorenko J, Kemper KE, Zheng Z, Wood AR, Weedon MN et al. Meta-

545 analysis of genome-wide association studies for height and body mass index in $\sim 700000$

546 individuals of European ancestry. Hum Mol Genet 2018;27:3641-9.

547 38. Bowden J, Davey Smith G, Burgess S. Mendelian randomization with invalid

548 instruments: effect estimation and bias detection through Egger regression. Int $\mathrm{J}$ Epidemiol

$549 \quad 2015 ; 44: 512-25$

550 39. Bowden J, Davey Smith G, Haycock PC, Burgess S. Consistent Estimation in

551 Mendelian Randomization with Some Invalid Instruments Using a Weighted Median

552 Estimator. Genet Epidemiol 2016;40:304-14. 
553 40. Hemani G, Bowden J, Davey Smith G. Evaluating the potential role of pleiotropy in

554 Mendelian randomization studies. Hum Mol Genet 2018;27:R195-r208.

555 41. Wang C, Zhan X, Liang L, Abecasis GR, Lin X. Improved ancestry estimation for

556 both genotyping and sequencing data using projection procrustes analysis and genotype

557 imputation. Am J Hum Genet 2015;96:926-37.

558 42. Chang CC, Chow CC, Tellier LC, Vattikuti S, Purcell SM, Lee JJ. Second-

559 generation PLINK: rising to the challenge of larger and richer datasets. Gigascience

$560 \quad 2015 ; 4: 7$.

561 43. Mägi R, Morris AP. GWAMA: software for genome-wide association meta-analysis.

562 BMC Bioinformatics 2010;11:288.

563 44. Howe G, Westhoff C, Vessey M, Yeates D. Effects of age, cigarette smoking, and

564 other factors on fertility: findings in a large prospective study. Br Med J (Clin Res Ed)

$565 \quad 1985 ; 290: 1697-700$.

566 45. Dallongeville J, Marécaux N, Fruchart JC, Amouyel P. Cigarette smoking is

567 associated with unhealthy patterns of nutrient intake: a meta-analysis. J Nutr

$568 \quad 1998 ; 128: 1450-7$

569 46. Ng R, Sutradhar R, Yao Z, Wodchis WP, Rosella LC. Smoking, drinking, diet and

570 physical activity-modifiable lifestyle risk factors and their associations with age to first

571 chronic disease. Int J Epidemiol 2020;49:113-30.

572 47. Perkins KA, Rohay J, Meilahn EN, Wing RR, Matthews KA, Kuller LH. Diet,

573 alcohol, and physical activity as a function of smoking status in middle-aged women.

$574 \quad$ Health Psychol 1993;12:410-5.

575 48. Agrawal A, Heath AC, Grant JD, Pergadia ML, Statham DJ, Bucholz KK et al.

576 Assortative mating for cigarette smoking and for alcohol consumption in female Australian

577 twins and their spouses. Behav Genet 2006;36:553-66. 
medRxiv preprint doi: https://doi.org/10.1101/2021.10.25.21265469; this version posted October 26, 2021. The copyright holder for this preprint (which was not certified by peer review) is the author/funder, who has granted medRxiv a license to display the preprint in perpetuity.

All rights reserved. No reuse allowed without permission.

578 49. Davies NM, von Hinke Kessler Scholder S, Farbmacher H, Burgess S, Windmeijer

579 F, Smith GD. The many weak instruments problem and Mendelian randomization. Stat

580 Med 2015;34:454-68.

581 50. Nilsen RM, Vollset SE, Gjessing HK, Skjaerven R, Melve KK, Schreuder P et al.

582 Self-selection and bias in a large prospective pregnancy cohort in Norway. Paediatr

583 Perinat Epidemiol 2009;23:597-608.

584 
587 Table 1. Comparison among multivariable logistic regression, one- and two-sample Mendelian randomization regarding sources of

588 bias in the association between smoking and subfertility

\begin{tabular}{|c|c|c|c|c|}
\hline & $\begin{array}{l}\text { Residual confounding } \\
\text { (the effect of smoking on subfertility } \\
\text { could be due to behavioral or } \\
\text { socioeconomic conditions intimately } \\
\text { related to smoking, such as poor } \\
\text { diet, poorer health status, etc.) }\end{array}$ & $\begin{array}{l}\text { Weak genetic instruments } \\
\text { (the available genetic instruments for } \\
\text { smoking traits explain a small } \\
\text { proportion of the variability of the } \\
\text { exposure) }\end{array}$ & $\begin{array}{l}\text { Horizontal pleiotropy } \\
\text { (the genetic instruments for smoking } \\
\text { traits influence the risk of subfertility } \\
\text { via mechanisms other than smoking) }\end{array}$ & $\begin{array}{l}\text { Confounding of the } \\
\text { genetic instrument- } \\
\text { outcome association } \\
\text { (by population stratification) }\end{array}$ \\
\hline $\begin{array}{l}\text { Multivariable } \\
\text { regression }\end{array}$ & High risk & Unaffected & Unaffected & Unaffected \\
\hline $\begin{array}{l}\text { One-sample } \\
\text { MR }\end{array}$ & Low risk & $\begin{array}{l}\text { Overestimated associations. } \\
\text { Consistence with two-sample MR } \\
\text { estimates minimizes the risk of this } \\
\text { bias }\end{array}$ & $\begin{array}{l}\text { Possibility to explore the association } \\
\text { between genetic instruments and } \\
\text { other subfertility risk factors. } \\
\text { Multivariable MR could then be used } \\
\text { to correct for such bias }\end{array}$ & $\begin{array}{l}\text { Adjustment for ancestry- } \\
\text { informative principal } \\
\text { components minimizes the } \\
\text { risk of this bias }\end{array}$ \\
\hline
\end{tabular}




\begin{tabular}{|l|l|l|l|}
\hline Two-sample & Low risk & Bias towards the null association. & Consistence among MR methods, \\
The Robust Adjusted Profile Score & approach is immune to this bias & $\begin{array}{l}\text { lack of between SNP heterogeneity, } \\
\text { and lack of outliers in MR scatterplots } \\
\text { minimizes the risk of this bias }\end{array}$ \\
\hline
\end{tabular}


medRxiv preprint doi: https://doi.org/10.1101/2021.10.25.21265469; this version posted October 26, 2021. The copyright holder for this preprint (which was not certified by peer review) is the author/funder, who has granted medRxiv a license to display the preprint in perpetuity. All rights reserved. No reuse allowed without permission.

Table 2. Population characteristics among genotyped participants

\begin{tabular}{|c|c|c|c|c|c|c|c|c|c|}
\hline & \multicolumn{4}{|c|}{ Women } & \multicolumn{5}{|c|}{ Men } \\
\hline & $\begin{array}{c}\text { All } \\
(n=28,606)\end{array}$ & $\begin{array}{l}\text { Subfertility } \\
\text { reported } \\
(n=3,439)\end{array}$ & $\begin{array}{l}\text { No subfertility } \\
\text { reported } \\
(n=25,167)\end{array}$ & $p$-value & $(n=$ & $\begin{array}{l}\text { All } \\
27,096)\end{array}$ & $\begin{array}{l}\text { Subfertility } \\
\text { reported } \\
(n=3,275)\end{array}$ & $\begin{array}{l}\text { No subfertility } \\
\text { reported } \\
(n=23,821)\end{array}$ & $p$-value \\
\hline $\begin{array}{l}\text { Age (years), } \\
\text { mean } \pm S D\end{array}$ & $30.3 \pm 4.15$ & $31.5 \pm 4.36$ & $30.2 \pm 4.09$ & $<0.001$ & 32.7 & \pm 4.90 & $34.1 \pm 5.36$ & $32.6 \pm 4.81$ & $<0.001$ \\
\hline $\begin{array}{l}\text { Education years, } \\
\text { mean } \pm S D\end{array}$ & $17.5 \pm 3.11$ & $17.0 \pm 3.33$ & $17.6 \pm 3.08$ & $<0.001$ & 16.6 & \pm 3.50 & $16.2 \pm 3.54$ & $16.6 \pm 3.49$ & $<0.001$ \\
\hline $\begin{array}{l}\mathrm{BMI}\left(\mathrm{kg} / \mathrm{m}^{2}\right) \\
\text { median }\left(25^{\text {th }}-75^{\text {th }} \text { percentiles }\right)\end{array}$ & $\begin{array}{c}23.1 \\
(21.2-25.9)\end{array}$ & $\begin{array}{c}23.7 \\
(21.5-27.2)\end{array}$ & $\begin{array}{c}23.1 \\
(21.1-25.7)\end{array}$ & $<0.001$ & & $\begin{array}{l}25.5 \\
7-27.7)\end{array}$ & $\begin{array}{c}25.8 \\
(24.0-28.1)\end{array}$ & $\begin{array}{c}25.4 \\
(23.7-27.7)\end{array}$ & $<0.001$ \\
\hline $\begin{array}{l}\text { Previous pregnancies } \\
n(\%):\end{array}$ & & & & $<0.001$ & & & & & $<0.001$ \\
\hline (r & $\begin{array}{l}12,888 \\
(45.1 \%)\end{array}$ & $\begin{array}{c}2,020 \\
(58.8 \%)\end{array}$ & $\begin{array}{c}10,868 \\
(43.2 \%)\end{array}$ & & & $\begin{array}{l}5.282 \\
5.4 \%)\end{array}$ & $\begin{array}{c}1,923 \\
(58.8 \%)\end{array}$ & $\begin{array}{c}10,359 \\
(43.5 \%)\end{array}$ & \\
\hline 1 or more & $\begin{array}{l}15,680 \\
(54.9 \%)\end{array}$ & $\begin{array}{c}1,415 \\
(41.2 \%)\end{array}$ & $\begin{array}{l}14,265 \\
(56.8 \%)\end{array}$ & & & $\begin{array}{l}.784 \\
.6 \%)\end{array}$ & $\begin{array}{c}1,348 \\
(41.2 \%)\end{array}$ & $\begin{array}{l}13,436 \\
(56.5 \%)\end{array}$ & \\
\hline $\begin{array}{l}\text { Ever smokers (all } \\
\text { participants), } n(\%):\end{array}$ & $\begin{array}{c}13,389 \\
(46.8 \%) \\
\end{array}$ & $\begin{array}{c}1,722 \\
(50.1 \%)\end{array}$ & $\begin{array}{l}11,667 \\
(46.4 \%)\end{array}$ & $<0.001$ & & $\begin{array}{l}186 \\
3.7 \%)\end{array}$ & $\begin{array}{c}1,668 \\
(50.9 \%)\end{array}$ & $\begin{array}{l}11,518 \\
(48.4 \%)\end{array}$ & 0.006 \\
\hline $\begin{array}{l}\text { Age of smoking initiation } \\
\text { (current }+ \text { former smokers), } \\
\text { median }\left(25^{\text {th }}-75^{\text {th }} \text { percentiles) }\right.\end{array}$ & $\begin{array}{c}17.0 \\
(15.0-19.0)\end{array}$ & $\begin{array}{c}16.0 \\
(15.0-18.0)\end{array}$ & $\begin{array}{c}17.0 \\
(15.0-19.0)\end{array}$ & 0.017 & & - & - & - & - \\
\hline $\begin{array}{l}\text { Current + former smokers } \\
\text { who quit smoking, } n(\%) \text { : }\end{array}$ & $\begin{array}{c}7,627 \\
(57.0 \%)\end{array}$ & $\begin{array}{c}910 \\
(52.8 \%)\end{array}$ & $\begin{array}{c}6,717 \\
(57.6 \%)\end{array}$ & $<0.001$ & & - & - & - & - \\
\hline \begin{tabular}{l|l} 
Cigarettes/we \\
(current smok \\
median $\left(25^{\text {th }}-\right.$
\end{tabular} & $\begin{array}{l}\mathrm{k} \\
5^{\text {th }} \text { percentiles) }\end{array}$ & $\begin{array}{c}42.0 \\
(10.0-70.0)\end{array}$ & $\begin{array}{c}52.5 \\
(12.0-105)\end{array}$ & $\begin{array}{r}40.0 \\
(10.0-7 \\
\end{array}$ & $0.0)$ & $<0.001$ & $\begin{array}{c}70.0 \\
(21.0-105)\end{array}$ & $\begin{array}{c}70.0 \\
(35.0-105)\end{array}$ & $\begin{array}{r}7 C \\
(21.0 \\
\end{array}$ \\
\hline
\end{tabular}


medRxiv preprint doi: https://doi.org/10.1101/2021.10.25.21265469; this version posted October 26, 2021. The copyright holder for this preprint (which was not certified by peer review) is the author/funder, who has granted medRxiv a license to display the preprint in perpetuity.

All rights reserved. No reuse allowed without permission.

592

Table 3. Description of genetic instrumental variables ${ }^{1}$

593

\begin{tabular}{|c|c|c|c|c|c|}
\hline \multicolumn{6}{|l|}{ Binary exposures } \\
\hline & $\begin{array}{c}\text { SNPS } \\
(n)\end{array}$ & $\begin{array}{c}\text { GRS value } \\
(\text { mean } \pm \text { SD) }\end{array}$ & $\begin{array}{l}\text { Likelihood of presenting the exposure } \\
\text { per each 1-point increase in the GRS } \\
\text { OR }(95 \% \mathrm{Cl})\end{array}$ & Pseudo- $R^{2}$ & $\begin{array}{l}\text { Area under } \\
\text { the ROC } \\
\text { curve }\end{array}$ \\
\hline $\begin{array}{l}\text { GRS for smoking } \\
\text { initiation (women) }\end{array}$ & 355 & $375 \pm 11.9$ & 1.02 (1.018 to 1.022$)$ & $1.87 \%$ & 0.57 \\
\hline $\begin{array}{l}\text { GRS for smoking } \\
\text { initiation (men) }\end{array}$ & 355 & $376 \pm 11.8$ & 1.02 (1.017 to 1.022$)$ & $1.69 \%$ & 0.56 \\
\hline $\begin{array}{l}\text { GRS for smoking } \\
\text { cessation (women) }\end{array}$ & 23 & $24.5 \pm 2.52$ & 1.03 (1.019 to 1.047$)$ & $0.22 \%$ & 0.52 \\
\hline \multicolumn{6}{|l|}{ Continuous exposures } \\
\hline & $\begin{array}{c}\text { SNPS } \\
(n)\end{array}$ & $\begin{array}{l}\text { GRS value } \\
\text { (mean } \pm \text { SD) }\end{array}$ & $\begin{array}{l}\text { Change in the exposure } \\
\text { per each 1-point increase in the GRS } \\
\text { Coef. }(95 \% \mathrm{Cl})\end{array}$ & $R^{2}$ & F-statistic \\
\hline $\begin{array}{l}\text { GRS for cigarettes } \\
\text { smoked per week (women) }\end{array}$ & 50 & $51.2 \pm 6.90$ & 0.80 (0.62 to 0.98$)$ & $1.43 \%$ & 76 \\
\hline $\begin{array}{l}\text { GRS for cigarettes } \\
\text { smoked per week (men) }\end{array}$ & 50 & $51.2 \pm 6.96$ & 0.87 (0.66 to 1.09$)$ & $1.34 \%$ & 64 \\
\hline $\begin{array}{l}\text { GRS for age of smoking } \\
\text { initiation (women) }\end{array}$ & 10 & $7.78 \pm 1.83$ & $0.023(-0.014$ to 0.059$)$ & $0.01 \%$ & 1 \\
\hline
\end{tabular}

594 1. The associations of smoking cessation and age of smoking initiation with their

595 respective GRSs in men could not be validated due to the lack of information on this

596 phenotype. 
medRxiv preprint doi: https://doi.org/10.1101/2021.10.25.21265469; this version posted October 26, 2021. The copyright holder for this preprint

(which was not certified by peer review) is the author/funder, who has granted medRxiv a license to display the preprint in perpetuity.

All rights reserved. No reuse allowed without permission.

\section{FIGURES}

598

599 Figure 1. Study flow chart

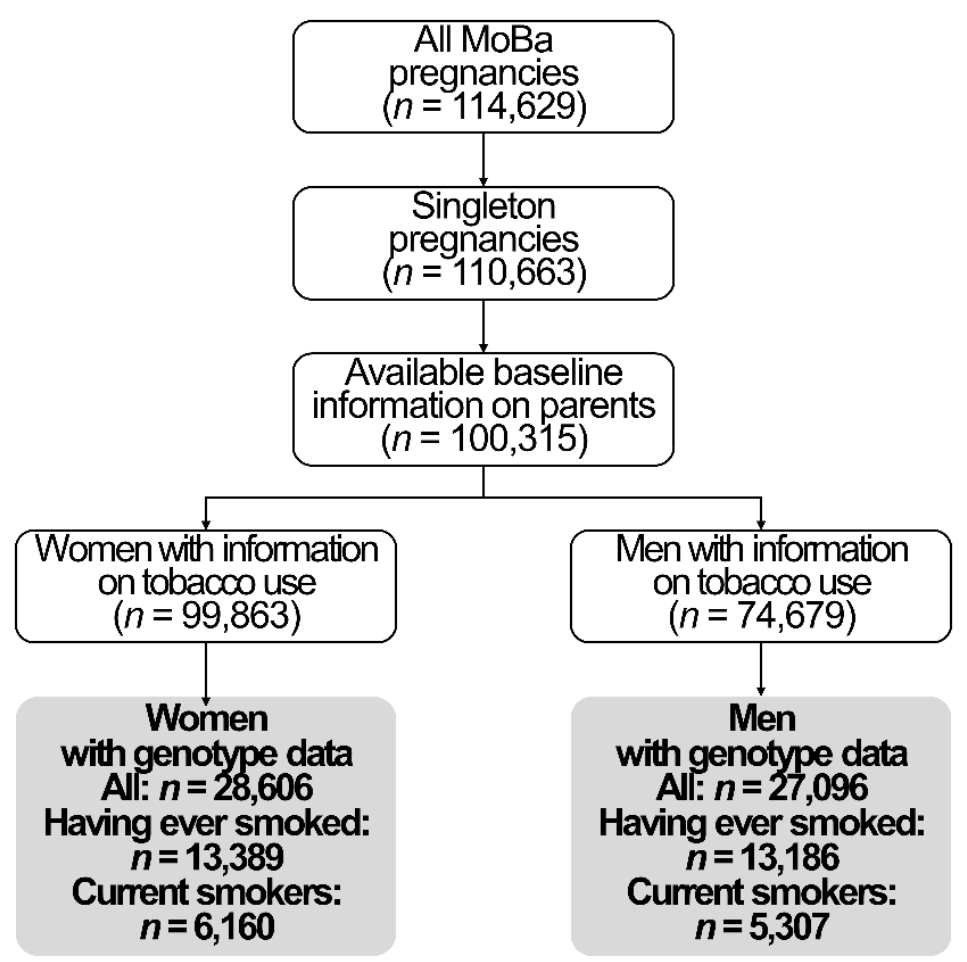


medRxiv preprint doi: https://doi.org/10.1101/2021.10.25.21265469; this version posted October 26, 2021. The copyright holder for this preprint (which was not certified by peer review) is the author/funder, who has granted medRxiv a license to display the preprint in perpetuity. All rights reserved. No reuse allowed without permission.

601 Figure 2. Association between smoking-related traits and subfertility in women (A) and men (B).

A Smoking initiation (all women)

Having ever smoked (vs. never having smoked), multivariable regression $+1 \mathrm{SD}$ in genetically-predicted likelihood of smoking initiation, one-sample MR $+1 \mathrm{SD}$ in genetically-predicted likelihood of smoking initiation, two-sample MR Smoking intensity (current smokers)

$+1 \mathrm{SD}$ in cigarettes smoked per week, multivariable regression

$+1 \mathrm{SD}$ in genetically-predicted number of cigarettes/week, one-sample MR

$+1 \mathrm{SD}$ in genetically-predicted number of cigarettes/week, two-sample MR Age of smoking initiation (current + former smokers)

$+1 \mathrm{SD}$ in age of smoking initiation, multivariable regression

$+1 \mathrm{SD}$ in genetically-predicted age of initiation, one-sample MR

$+1 \mathrm{SD}$ in genetically-predicted age of initiation, two-sample MR Smoking cessation (current + former smokers)

Quitting smoking (vs. no smoking cessation), multivariable regression

$+1 \mathrm{SD}$ in genetically-predicted likelihood of smoking cessation, one-sample MR

$+1 \mathrm{SD}$ in genetically-predicted likelihood of smoking cessation, two-sample MR

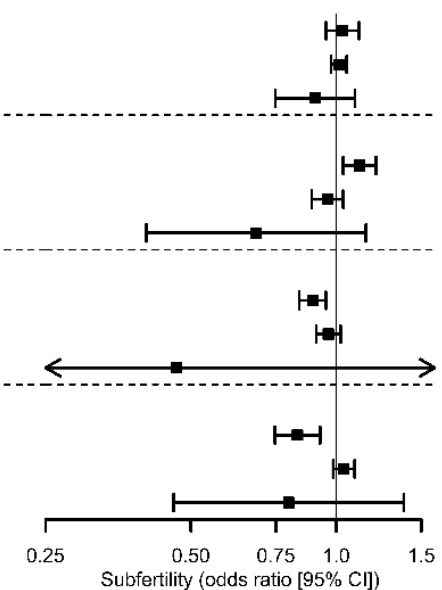

$1.03(0.95$ to 1.11$)$

$1.01(0.98$ to 1.05$)$

$0.90(0.75$ to 1.09$)$

$1.12(1.03$ to 1.21$)$

$0.96(0.89$ to 1.03$)$

$0.68(0.40$ to 1.15$)$

$0.89(0.84$ to 0.95$)$

$0.96(0.91$ to 1.02$)$

0.47 (0.11 to 2.01 )

$0.83(0.75$ to 0.93$)$

1.04 (0.99 to 1.09$)$

$0.80(0.46$ to 1.38$)$

B Smoking initiation (all men)

Having ever smoked (vs. never having smoked), multivariable regression

$+1 \mathrm{SD}$ in genetically-predicted likelihood of smoking initiation, one-sample MR

$+1 \mathrm{SD}$ in genetically-predicted likelihood of smoking initiation, two-sample MR Smoking intensity (current smokers)

+1 SD in cigarettes smoked per week, multivariable regression

$+1 \mathrm{SD}$ in genetically-predicted number of cigarettes/week, one-sample MR

$+1 \mathrm{SD}$ in genetically-predicted number of cigarettes/week, two-sample MR

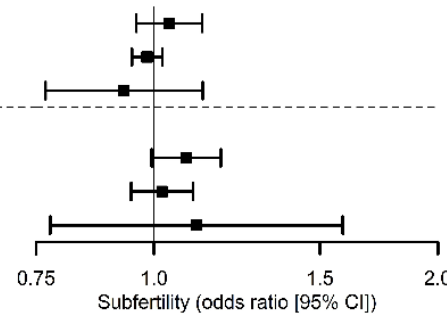

$1.04(0.96$ to 1.12$)$

$0.99(0.95$ to 1.03$)$

$0.93(0.77$ to 1.13$)$

$1.08(0.99$ to 1.18$)$

$1.02(0.95$ to 1.10$)$

$1.11(0.78$ to 1.59$)$ 